\title{
Antifungal piperamides from Piper mollicomum Kunth (Piperaceae)
}

\author{
Herlle Aparecido da Silva ${ }^{1}$, Lydia Fumiko Yamaguchi ${ }^{2} \oplus$, Maria Cláudia Marx Young ${ }^{3}$, Clécio Souza $\operatorname{Ramos}^{4} \oplus$, \\ André Márcio Araújo Amorim ${ }^{5}$, Massuo Jorge Kato ${ }^{2}$, Ronan Batista ${ }^{6+}$ () \\ ${ }^{1}$ State University of Southeast of Bahia, BR 415 Hwy, Km 03, Itapetinga, Bahia, Brazil \\ ${ }^{2}$ University of São Paulo (USP), Institute of Chemistry, 748 Prof. Lineu Prestes Av, São Paulo, São Paulo, Brazil \\ ${ }^{3}$ Institute of Botany, 3687 Miguel Stéfano Av, São Paulo, São Paulo, Brazil \\ ${ }^{4}$ Federal Rural University of Pernambuco (UFRPE), Dom Manoel de Medeiros St, Recife, Pernambuco, Brazil \\ ${ }^{5}$ State University of Santa Cruz (UESC), Ilhéus-Itabuna Hwy, Km 16, Ilhéus, Bahia, Brazil \\ ${ }^{6}$ Federal University of Bahia (UFBA), Barão de Jeremoabo St, Salvador, Bahia, Brazil
}

+ Corresponding author: Ronan Batista, phone: +55 71 3283-6841, e-mail address: ronbatis@ufba.br

\section{ARTICLE INFO}

Article history:

Received: January 26, 2018

Accepted: April 20, 2018

Published: May 29, 2018
Keywords:

\section{Piperaceae}

2. Piper mollicomum

3. antifungal compounds

4. direct bioautography

5. piperamides
ABSTRACT: The phytochemical study on dichlorometane extracts of leaves, stem and roots of Piper mollicomum Kunth (Piperaceae) led to isolation of the known piperamides tembamide (1), $(R)-(-)-$ tembamide acetate (2) and riparin I (3). Compounds 1 and 2 displayed moderate in vitro antifungal activity against Cladosporium cladosporioides $(5.0 \mu \mathrm{g})$ and Cladosporium sphaerospermum (1.0 $\mu \mathrm{g}$ ) by direct bioautographic analyses and compound 3 was inactive up to $100.0 \mu \mathrm{g}$.

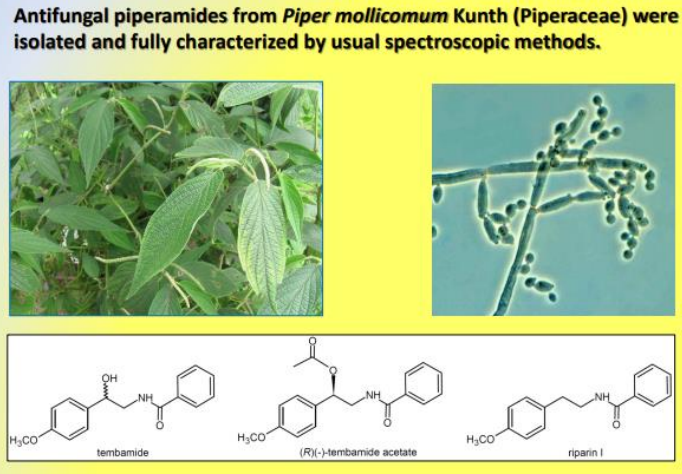

\section{Introduction}

Piperaceae family belongs to the Piperales order and it is one of the most primitive families among Angiosperms. It is predominantly a tropical family, comprising the genera Piper, Peperomia, Sarchorhachis and Ottonia, from which Piper and Peperomia are the most representative ones with approximately 2000 and 1700 species, respectively ${ }^{1,2}$. Piperaceae species have long been used as food additive and folk medicine agents mainly due to their antimicrobial properties, including potent fungicidal action ${ }^{3}$.

Piper species usually possess strong and pleasant aroma and spicy flavor, which explain their use as condiments, flavorings and medicinal materials. Piper compounds are often grouped into seven general classes, including amides, lignans, neolignans, flavonoids, kavalactones, butenolides, and volatile oils ${ }^{4,5}$. Amides are one of the most characteristic constituents of Piper species ${ }^{6}$. The biological activities presented by Piper's amides (also known as "piperamides") have inspired 
synthetic studies towards the preparation of analogs of these substances, in order to evaluate their potential for commercial and medical use $\mathrm{u}^{7}$. As result, many of these analogs revealed promising antifungal and insecticidal properties ${ }^{3,8-10}$.

Known as "jaborandi-manso" or simply "jaborandi", the species Piper mollicomum Kunth is a small shrub of 1.0 to $1.5 \mathrm{~m}$ in height, found in Brazil in the states of São Paulo, Minas Gerais, Rio de Janeiro, Espírito Santo, Bahia, Santa Catarina, Ceará, Paraíba, Pernambuco, Mato Grosso and Goiás. The fruits of $P$. mollicomum Kunth are popularly used to treat stomach problems, and its roots, when chewed, are useful for anesthetizing toothaches ${ }^{11}$. Nevertheless, few studies with $P$. mollicomum Kunth have been performed so far. From $P$. mollicomum methanolic extracts, the<smiles>COc1ccc([C@@H](O)CNC(=O)c2ccccc2)cc1</smiles><smiles>COc1ccc(CCNC(=O)c2ccccc2)cc1</smiles><smiles>COC(=O)c1ccc2c(c1)C=CC(C)(C)O2</smiles>

5 chromenes methyl 2,2-dimethyl-2H-chromene-6carboxylate (4) and methyl 8-hydroxy-2,2dimethyl-2H-chromene-6-carboxylate (5), along with the dihydrochalcone 2',6'-dihydroxy-4'methoxychalcone (6), were isolated and displayed antifungal properties against the fungi Cladosporium cladosporioides and Cladosporium sphaerospermum ${ }^{12}$.

The present study aimed to further investigate the chemical composition of $P$. mollicomum Kunth dichlorometane extracts. The compounds tembamide (1), $(R)$-(-)-tembamide acetate (2) and riparin I (3) were isolated and characterized and compounds 1 and 2 were found to display in vitro antifungal activity against Cladosporium cladosporioides and C. sphaerospermum.<smiles>COc1ccc([C@H](CNC(=O)c2ccccc2)OC(C)=O)cc1</smiles><smiles>COC(=O)c1cc(O)c2c(c1)C=CC(C)(C)O2</smiles><smiles>COc1cc(O)c(C(=O)CCc2ccccc2)c(O)c1</smiles>

Figure 1. Tembamide (1), $(R)$-(-)-tembamide acetate (2), riparin I (3), methyl 2,2-dimethyl-2Hchromene-6-carboxylate (4), methyl 8-hydroxy-2,2-dimethyl-2H-chromene-6-carboxylate (5) and 2',6'dihydroxy-4'-methoxychalcone (6) isolated from Piper mollicomum Kunth.

\section{Experimental}

\subsection{General procedures}

Optical rotation was measured on a PerkinElmer 241 polarimeter. ${ }^{1} \mathrm{H}$ and ${ }^{13} \mathrm{C}$ NMR spectra were recorded at 500 and $125 \mathrm{MHz}$, respectively, on a Bruker DRX. $\mathrm{CDCl}_{3}$ (Aldrich) was used as solvent and TMS as internal standard. Chemical shifts were reported in $\delta$ units (ppm) and coupling constants $(J)$ in Hz. MS spectra were obtained on a GGEM SHIMADZU mass spectrometer $(70 \mathrm{eV})$ apparatus GCMS-QP5050A, equipped with BPX5 capillary column $(30 \mathrm{~m} \times 0.25 \mathrm{~mm}$ ID). Silica gel 
(Macherey-Nagel, 70-230 mesh) was used for column chromatographic separations, while silica gel 60G (Acros Organic) was used for analytical TLC chromatography.

\subsection{Plant material}

The plant was collected in Firmino Alves, southern Bahia, Brazil, in April 2009, and a voucher specimen was housed in the Herbarium of the Executive Committee of the Cacao Plan (CEPLAC) in Ilhéus, Bahia, under the code "PIPER-007", and identified as Piper mollicomum Kunth by Dr. André Márcio Araújo Amorim (Bahia State University of Santa Cruz - UESC). The collected material was dried in an oven $\left(50{ }^{\circ} \mathrm{C}\right)$ for 48 hours, and their separated parts (stem, leaf and root) were pulverized in a knife mill.

\subsection{Obtaining extracts}

The dried and pulverized leaves (28 g), stem $(128 \mathrm{~g})$ and roots $(200 \mathrm{~g})$ were thoroughly extracted by maceration with dichloromethane, and then concentrated under reduced pressure $\left(38{ }^{\circ} \mathrm{C}\right)$ until complete removal of the solvent, affording the dichlorometane extracts of the roots $(1.68 \mathrm{~g})$, stem $(1.31 \mathrm{~g})$ and leaves $(1.19 \mathrm{~g})$.

\subsection{Fractionating extracts}

The crude extract from roots $(1.68 \mathrm{~g})$ was subjected to silica gel column chromatography ( $\mathrm{Si}$ $\mathrm{CC}$ ) eluting with mixtures of hexane, ethyl acetate (EtOAc) and methanol $(\mathrm{MeOH})$ with increasing polarities, yielding a total of 55 fractions. Two fractions eluted with EtOAc were further processed. The fraction $24(45 \mathrm{mg})$ was treated with ethyl ether to provide $(R)$-(-)-tembamide acetate $(2,28 \mathrm{mg})$, and the fraction $26(245 \mathrm{mg})$ was submitted again to Si-CC (hexane-EtOAc, 1:1) to produce tembamide $(1,31 \mathrm{mg})$. Additional amounts of $1(6 \mathrm{mg})$ and $2(5 \mathrm{mg})$ were isolated when crude extracts from stems $(1.31 \mathrm{~g})$ were fractionated by similar procedure.

The crude dichloromethane extract from leaves $(1.19 \mathrm{~g})$ was also submitted to Si-CC using mixtures of hexane, EtOAc and $\mathrm{MeOH}$ with increasing polarities to afford 87 fractions. Fractions 76 to 80 , eluted with hexane-EtOAc (7:3), were grouped (13 mg) and submitted to prepTLC (hexane-EtOAc, 6:4) to yield riparin I (3, 5 $\mathrm{mg})$.
Tembamide (1). ${ }^{1} \mathrm{H}$ NMR (500 MHz, $\mathrm{CDCl}_{3}$ ): $\delta$ $7.75(\mathrm{~d}, 2 \mathrm{H}, J=8.0 \mathrm{~Hz}), 7.51(\mathrm{dd}, 1 \mathrm{H}, J=7.5,7.0$ $\mathrm{Hz}), 7.43(\mathrm{dd}, 2 \mathrm{H} J=8.0,7.0 \mathrm{~Hz}), 7.33(\mathrm{~d}, 2 \mathrm{H}, J$ $=8.5 \mathrm{~Hz}), 6.90(\mathrm{~d}, 2 \mathrm{H}, J=8.5 \mathrm{~Hz}), 6.59$ (br. s, $1 \mathrm{H})$, $4.91(\mathrm{dd}, 1 \mathrm{H}, J=8.0,3.5 \mathrm{~Hz}), 3.90-3.86(\mathrm{~m}, 1 \mathrm{H})$, $3.81(\mathrm{~s}, 3 \mathrm{H}), 3.54-3.49(\mathrm{~m}, 1 \mathrm{H}) ;{ }^{13} \mathrm{C}$ NMR $(125$ $\left.\mathrm{MHz}, \mathrm{CDCl}_{3}\right): \delta 168.53,159.18,134.12,133.85$, 131.67, 128.60, 127.09, 126.96, 113.99, 73.33, 55.30 and 47.73; EM-IES (m/z): $294.1124(\mathrm{M}+$ $\mathrm{Na})^{+} ;\left[\mathrm{C}_{16} \mathrm{H}_{17} \mathrm{NO}_{3}\right.$ requires $\left.(\mathrm{M}+\mathrm{Na})^{+}=294.1095\right]$.

(R)-(-)-Tembamide acetate $(2) .[\alpha]_{\mathrm{D}}=-43.9^{\circ}(c$ $0.55), \mathrm{CHCl}_{3} .{ }^{1} \mathrm{H}$ NMR $\left(500 \mathrm{MHz}, \mathrm{CDCl}_{3}\right): \delta 7.72$ $(\mathrm{d}, J=8.0 \mathrm{~Hz}, 2 \mathrm{H}), 7.50(\mathrm{t}, J=7.0 \mathrm{~Hz}, 1 \mathrm{H}), 7.43$ $(\mathrm{dd}, J=8.0,7.0 \mathrm{~Hz}, 2 \mathrm{H}), 7.33(\mathrm{~d}, J=8.5 \mathrm{~Hz}, 2 \mathrm{H})$, $6.91(\mathrm{~d}, J=8.5 \mathrm{~Hz}, 2 \mathrm{H}), 6.41$ (br. s, $1 \mathrm{H}), 5.94$ (dd, $J=7.5,5.5 \mathrm{~Hz}, 1 \mathrm{H}), 3.82-3.85(\mathrm{~m}, 2 \mathrm{H}), 3.81(\mathrm{~s}$, $3 \mathrm{H}), 2.10$ (s, 3H). ${ }^{13} \mathrm{C}$ NMR (125 MHz, $\left.\mathrm{CDCl}_{3}\right): \delta$ $170.76,167.43,159.76,134.27,131.58,129.65$, 128.62, 127.94, 126.86, 114.14, 74.34, 55.30, 45.01, 21.23; EM-IES $(\mathrm{m} / z): 336.1204(\mathrm{M}+\mathrm{Na})^{+}$; $\left[\mathrm{C}_{18} \mathrm{H}_{19} \mathrm{NO}_{4}\right.$ requires $\left.(\mathrm{M}+\mathrm{Na})^{+}=336.1201\right]$.

Riparin I (3). ${ }^{1} \mathrm{H}$ NMR $\left(500 \mathrm{MHz}, \mathrm{CDCl}_{3}\right): \delta$ 7.67-7.70 (m, 2H), $7.16(\mathrm{~d}, J=8.5 \mathrm{~Hz}, 2 \mathrm{H}), 7.46-$ $7.49(\mathrm{~m}, 1 \mathrm{H}), 7.38-7.42(\mathrm{~m}, 2 \mathrm{H}), 6.87(\mathrm{~d}, J=8.5$ $\mathrm{Hz}, 2 \mathrm{H}$ ), 6.10 (br. s, 1H), 3.80 (s, 3H), 3.68 (q, $J=$ $7.0 \mathrm{~Hz}, 2 \mathrm{H}), 2.88(\mathrm{t}, J=7.0 \mathrm{~Hz}, 2 \mathrm{H}) ;{ }^{13} \mathrm{C}$ NMR $(125$ $\left.\mathrm{MHz}, \mathrm{CDCl}_{3}\right): \delta 167.42,158.35,134.69,131.37$, $130.83,129.75,128.55,126.77,114.14,52.27$, 41.27, 34.77; EM-IES (m/z): $255.1209(\mathrm{M})^{+}$, $256.1322(\mathrm{M}+1)^{+}, 254.1201$ referring to $[(\mathrm{M}-$ $2 \mathrm{H})+1]^{+} ;\left[\mathrm{C}_{16} \mathrm{H}_{17} \mathrm{NO}_{2}\right.$ requires $(\mathrm{M})^{+}=255.1254$, $(\mathrm{M}+1)^{+}=256.1332$, and $\left.(\mathrm{M}-1)^{+}=254.1176\right]$.

\subsection{Antifungal assay by direct bioautography}

The microorganisms used in the antifungal assays Cladosporium cladosporioides (Fresen.) de Vries SPG 140 and C. sphaerospermum (Penzig) SPC 491 were grown in Sabouraud dextrose agar, and maintained at the Instituto de Botânica, São Paulo, SP, Brazil. Both fungi were cultured in Sabouraud medium before the assay. Direct bioautography assays were performed in triplicate in agreement with the literature procedure ${ }^{9,13}$. Ten microliters of dichloromethane solutions prepared for each pure compound, corresponding to 100,50, $25,10,5$, and $1 \mu \mathrm{g}$, were applied to TLC plates and eluted with hexanes-EtOAc (7:3) followed by complete removal of the solvent at room temperature. The chromatograms were then sprayed with a spore suspension $\left(3 \times 10^{6}\right.$ cells $\left./ \mathrm{mL}\right)$ in glucose and salt solution and incubated for $48 \mathrm{~h}$ in the darkness in a moistened chamber at $25{ }^{\circ} \mathrm{C}$. 
Clear inhibition zones appeared against a dark background, indicating the minimal amount of compound required to inhibit the growth of each fungus (Table 1). Nystatin was used as the positive control (detection limit $1 \mu \mathrm{g}$ ).

\section{Results and discussion}

The phytochemical study on dichlorometane extracts of the leaves, stem and roots of Piper mollicomum Kunth led to the isolation of the known compounds tembamide (1), (R)-(-)tembamide acetate (2) and riparin I (3) (Figure 1), from which only 1 and 2 were found to exhibit remarkable antifungal properties against Cladosporium cladosporioides $(5 \mu \mathrm{g})$ and $C$. sphaerospermum $(1 \quad \mu \mathrm{g})$ through direct bioautography analyses. When tested against $C$. sphaerospermum, compounds 1 and 2 were shown to be as potent as nystatin, the positive control (Table 1 ). The acetate 2 could be easily hydrolysed by fungal enzymes and this could be one likely explanation for the same antifungal activity observed for both compounds 1 and 2. In spite of being already known chemical entities, the compounds 1-3 are reported here, for the first time, as chemical constituents of $P$. mollicomum Kunth. In addition, bearing in mind that only 1 and 2 were active against the assayed fungi, but not 3 , one can hypothesize that such antifungal activity may be related to the oxygenation at the benzylic carbon, explaining why 3 was inactive against the both fungi assayed.

Tembamide is widely described as a chemical constituent of plants belonging to the Rutaceae family, such as Clausena brevistyla Oliver ${ }^{14}$, Zanthoxylum ekmanii (URB.) ALAIN ${ }^{15}$, Aegle marmelos $^{16}$, Clausena lansium ${ }^{17}$, and Feroniella lucida $^{18}$. This amide was also obtained by hydrolysis from tembamide acetate isolated from the dichloromethane fraction of Piper guayranum (Piperaceae) ${ }^{19}$, a plant species traditionally used in Indian medicine due to its hypoglycemic activity ${ }^{20}$. In addition, tembamide displayed one of the most potent activities against HIV virus among 67 substances isolated from the bark and root of Zanthoxylum ailanthoides (Rutaceae) ${ }^{21}$. Isolated from Zanthoxylum capense (Rutaceae), tembamide was also evaluated along with $(R)-(+)$-tembamide acetate in tests of antibiotic modulators ${ }^{22}$. Its synthesis has been previously described by Aguirre et al. (2001) and Kamal et al. (2004) $)^{23}, 24$. According to literature data, riparine I, isolated from the fruits of Aniba riparia (Nees) $\mathrm{Mez}$ (Lauraceae), presented anxiolytic effects ${ }^{25}$ and it was shown to be a potent muscle relaxant ${ }^{26}$.

Our findings call attention to the importance of $P$. mollicomum Kunth as a source of bioactive natural compounds for further studies on promising antimicrobial and pharmacological agents.

Table 1. Antifungal activity of compounds from P. mollicomum Kunth against Cladosporium species.

\begin{tabular}{|c|c|c|}
\hline \multirow{2}{*}{ compounds } & \multicolumn{2}{|c|}{ Antifungal Activity $(\mu \mathrm{g})^{\mathrm{a}}$} \\
\hline & C. cladosporioides & C. sphaerospermum \\
\hline Tembamide (1) & 5.0 & 1.0 \\
\hline$(R)-(-)$-Tembamide acetate $(2)$ & 5.0 & 1.0 \\
\hline Riparin I (3) & $>100.0$ & $>100.0$ \\
\hline Nystatin & 1.0 & 1.0 \\
\hline
\end{tabular}

${ }^{a}$ Minimum amount required for inhibition of fungal growth on thin layer chromatography (TLC) plate.

\section{Conclusions}

The present study reports on the chemical constituents of Piper mollicomum Kunth, in which the piperamides tembamide, $(R)-(-)$-tembamide acetate and riparin I, bioactive compounds commonly isolated from Rutaceae species. Tembamide and $(R)-(-)$-tembamide acetate showed antifungal activity as potent as nystatin 
against Cladosporium strains by means of direct bioautographic analyses.

\section{Acknowledgements}

The authors are grateful to the Brazilian agencies FAPESB (DCR0051/20107) and FAPESP (2005/51850-9 and 2014/50316-7) for grants and financial support.

\section{References}

[1] Mabberley, D. J., The plant-book - a portable dictionary of the higher plants, Cambridge University Press, New York, 1997.

[2] Souza, V. C., Botânica Sistemática: guia ilustrado para identificação das famílias de Angiosperma da flora brasileira baseado em APG II, Instituto Plantarum, Nova Odessa, 2005.

[3] Navickiene, H. M. D., Miranda, J. E., Bortoli, S. A., Kato, M. J., Bolzani, V. S., Furlan, M., Toxicity of extracts and isobutyl amides from Piper tuberculatum: potent compounds with potential for the control of the velvet bean caterpillar Anticarsia gemmatalis, Pest Manag. Sci. 63 (2007) 399-403. https://doi.org/10.1002/ps.1340.

[4] Rorig, L. R., Poser, G. L. von, Investigação fitoquímica em espécies de Piperaceae, Rev. Bras. Farm. 72 (1) (1991) 15-17.

[5] Scott, I. M., Jensen, H. R., Philogène, B. J. R., Arnason, J. T., A review of Piper spp. (Piperaceae): phytochemistry, insecticidal activity and mode of action, Phytochem. Rev. 7 (2008) 6575. https://doi.org/10.1007/s11101-006-9058-5.

[6] Srinivasan, K., Black pepper and its pungent principle-piperine: a review of diverse physiological effects, Crit. Rev. Food Sci. 47 (2007) 735-748. https://doi.org/10.1080/10408390601062054.

[7] Dyer, L. A., Palmer, A. N., Piper: a model genus for studies of evolution, chemical ecology and tropic interactions, Klumer Academic Publishers, New York, 2004, ch7.
[8] Alécio, A. C., Bolzani, V. D., Young, M. C. M., Kato, M. J., Furlan, M., Antifungal amide from leaves of Piper hispidum, J. Nat. Prod. 61 (1998) 637-639. https://doi.org/10.1021/np9703656.

[9] Marques, J. V., Kitamura, R. O. S., Lago, J. H. G., Young, M. C. M., Guimaraes, E. F., Kato, M. J. Antifungal amides from Piper scutifolium and Piper hoffmanseggianum, J. Nat. Prod. 70 (2007) 2036-2039. https://doi.org/10.1021/np070347g.

[10] Navickiene, H. M. D., Alécio, A. C., Kato, M. J., Bolzani, V. S., Young, M. C. M., Cavalheiro, A. J., Furlan, M. Antifungal amides from Piper hispidum and Piper tuberculatum, Phytochemistry $55 \quad$ (2) (2000) 621-626. https://doi.org/10.1016/S0031-9422(00)00226-0.

[11] Guimarães, E. F., Giordano, L. C. S., Piperaceae do Nordeste Brasileiro I: estado do Ceará, Rodriguesia 55 (2004) 21-46. https://doi.org/10.1590/2175-78602004558402.

[12] Lago, J. H. G., Young, M. C. M., Reigada, J. B., Soares, M. G., Roesler, B. P., Kato, M. J. Antifungal derivatives from Piper mollicomum and P. lhotzkyanum (Piperaceae), Quím. Nova 30 (5) (2007) 1222-1224. https://doi.org/10.1590/S010040422007000500032.

[13] Santos, R. A., Ramos, C. S., Young, M. C. M., Pinheiro, T. G., Amorim, A. M., Kato, M. J., Batista, R., Antifungal constituents from the roots of Piper dilatatum Rich., J. Chem. article 160165 (2013) 1-5. https://doi.org/10.1155/2013/160165.

[14] Johns, S. R., Lamberton, J. A., Price, J. R., ( \pm N-Benzoyl[2-Hydroxy-2-(4'-

methoxyphenyl)] ethylamine from Clausena Brevistyla Oliver (Family Rutaceae), Aust. J. $\begin{array}{llll}\text { Chem. } & 20 & \text { (1967) 2795-2797. }\end{array}$ https://doi.org/10.1071/CH9672795.

[15] Facundo, V. A., da Silveira, A. S. P., Braz Filho, R., Pinto, A. C., Rezende, C. M., Constituintes químicos de Zanthoxylum ekmanii (Urb.) Alain. Quím. Nova 28 (2) (2005) 224-225. https://doi.org/10.1590/S010040422005000200010.

[16] Phuwapraisirisan, P., Puksasook, T., JongAramruang, J., Kokpol, U., Phenylethyl cinnamides: a new series of $\alpha$-glucosidase 
inhibitors from the leaves of Aegle marmelos, Bioorg. Med. Chem. Lett. 18 (2008) 4956-4958. https://doi.org/10.1016/j.bmcl.2008.08.024.

[17] Song, W-W., Zeng, G-Z., Peng, W-W., Chen, K-X., Tan, N-H., Cytotoxic amides and quinolones from Clausena lansium, Helv. Chim. Acta 97 (2014) 29.8-305. https://doi.org/10.1002/hlca.201300323.

[18] Sriyatep, T., Chakthong, S., Leejae, S., Voravuthkunchai, S. P., Two lignans, one alkaloid, and flavanone from the twigs of Feroniella lucida,

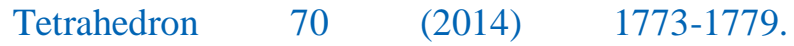
https://doi.org/10.1016/j.tet.2014.01.023.

[19] Maxwell, A., Ramprasad, D., $\beta$ Phenylethylamine-derived amides from Piper guayranum, J. Nat. Prod. 52 (2) (1989) 411-414. https://doi.org/10.1021/np50062a037.

[20] Shoeb, A., Kapil, R. S., Popli, S. P., Coumarins and alkaloids of Aegle marmelos, Phytochemistry $12 \quad$ (1973) 2071-2072. https://doi.org/10.1016/S0031-9422(00)91550-4.

[21] Singh, I. P., Bodiwala, H. S., Recent advances in anti-HIV natural products, Nat. Prod. Rep. 27 (2010) 1781-1800. https://doi.org/10.1039/c0np00025f.

[22] Cabral, V., Luo, X., Junqueira, E., Costa, S. S., Mulhovo, S., Duarte, A., Couto, I., Viveiros, M., Ferreira, M-J. U., Enhancing activity of antibiotics against Staphylococcus aureus: Zanthoxylum capense constituents and derivatives, Phytomedicine $22 \quad$ (2015) 469-476. https://doi.org/10.1016/j.phymed.2015.02.003.

[23] Aguirre, G., Salgado-Rodríguez, A., FloresLópez, L. Z., Parra-Hake, M., Somanathan, R., Asymmetric synthesis of naturally occuring $\beta$ hydroxyamides $(R)$-tembamide and $(R)$-aegeline, Rev. Soc. Quím. Mex. 45 (1) (2001) 21-24. Available from: http://www.scielo.org.mx/scielo.php?script=sci_ar ttext\&pid=S0583-

$76932001000100005 \& \operatorname{lng}=\mathrm{en} \& \mathrm{nrm}=\mathrm{iso} \& \operatorname{tn} \mathrm{g}=\mathrm{en}$.

[24] Kamal, A., Shaik, A. A., Sandbhor, M., Malik, S. M., Chemoenzymatic synthesis of $(R)$ - and $(S)$ tembamide, aegeline and denopamine by a one-pot lipase resolution protocol, Tetrahedron: Asymm.
15 (2004)

3939-3944.

https://doi.org/10.1016/j.tetasy.2004.11.013.

[25] Sousa, F. C. F., Monteiro, A. P., Melo, C. T. V., Oliveira, G. R., Vasconcelos, S. M. M., Fonteles, M. M. F., Gutierrez, S. J. C., Barbosafilho, J. M., Viana, G. S. B., Antianxiety effects of riparin I from Aniba riparia (Nees) Mez (Lauraceae) in mice, Phytother. Res. 19 (2005) 1005-1008. https://doi.org/10.1002/ptr.1771.

[26] Castelo-Branco, U. V., Castelo-Branco, U. J. V., Thomas, G., Araújo, C. C., Barbosa-Filho, J. M., Preliminary pharmacological studies on three benzoyl amides, constituents of Aniba riparia (Nees) Mez (Lauraceae), Acta Farm. Bon. 19 (3) (2000) 197-202. 